\title{
The Impact Of Parent Class On Parent Engagement In Children's Education
}

\author{
LENNI ARTA F S SINAGA \\ Post Graduate of Univesitas Negeri Medan \\ lenniarta2013@gmail.com \\ PANINGKAT SIBURIAN \\ Professor at Universitas Negeri Medan \\ North Sumatra, Indonesia \\ PANIGORAN SIBURIAN \\ Lecturer of Universitas Prima \\ North Sumatra Indonesia
}

\begin{abstract}
Information about parents in education of children is very important because parents are the primary and first educators, so they must complete themselves. Parent class is a means to build awareness of parents / guardians to be involved in education of children, including the development of a safe, comfortable, and enjoyable learning environment. Parents class is conducted at least twice as much as those coordinated by the association of parents and is guided by the teacher or the school. Researchers have proven a great deal about parental classrooms towards increasing parental knowledge in parenting. Parents who always increase their knowledge about how to educate children will have better knowledge in education of children. Parents in education of children will also improve achievement of children and character. However, parents who do not care and are not involved in education of children will have a negative impact on achievement of children. In general, the results of this study prove the existence of a parent class program to parents in school children at home, in the community and at school. From the results of the analysis of the effectiveness of the parent class using the paired sample $t$ test, information was obtained that all parental support variables had a significant change in value ( 2 tailed) at 0.001 (below 0.05), meaning that the independent variable was significant after the parent class was carried out. The school as the organizer of the parent class must implement the parent class starting from planning, implementing and evaluating. The class of parents is implemented at least twice in 4 state junior high
\end{abstract}


schools in Binjai, namely SMP 5.SMP 6.SMP 9 and SMP 12 in Binjai. From the research data approved by the 4 schools proceed to the class of sustainable parents and school principals who approve the policy and set out in the Annual Work Plan.

Keywords: parent class, parent participation, children's education

\section{Introduction}

Education in schools must be run in harmony with education in the family so that educational goals can be achieved better, because actually education first and foremost is a family with parents as educators. Family care may be natural for some people, while others may need additional support and guidance to understand a child's development, respond appropriately to their child's needs, and overcome the challenges of care.

Parents have obligations and responsibilities to: a. Caring for, caring for and protecting children; b. Developing children according to their abilities, talents, and interests; $c$. Preventing marriage at the age of the child; d. Providing character education and instilling the value of character in children (RI Law NO.35 of 2014 Article 26 paragraph (1) concerning child protection. Parents should always try to improve their insights, knowledge, and skills through various ways to learn the strategies of caring for their children to develop physically, emotionally and cognitively and can provide a positive and comfortable home environment for children's growth and development.

Parent class is an activity that aims to build awareness of parents / guardians of the importance of engaging in children's education, including developing a safe, comfortable and enjoyable learning environment. Parents class as a family engagement program at school as explained in Minister of Education Regulation No. 30 of 2017 and Regulation of the Directorate General of Early Childhood Education and Society No.127 in 2017.

Parent education programs aim to maximize positive outcomes for children and families. (National Academies of Science, Engineering, and Medicine, 2016), significant benefits for parents, caregivers, children, and families (more positive parenting style; Improved social relations; child behavior; mental health and parental well-being; Reducing the risk of punishment physical abuse and child abuse; self-confidence and empowerment of parents along with advancing parenting skills and parents growing more competent and comfortable in their roles (Wilder Research. (2016).

Family involvement in the administration of education has a close relationship with 
children's achievement outcomes (Wilkes: 2014), Improving the academic achievements of their children (Kimaro: 2015), significantly influencing the success of parents, children, teachers, and schools (Kemdikbud: 2017), improving academic and nonacademic achievements of students (Pramono: 2017), helping children's creativity programs (Khasanah: 2017), and is a key factor in improving children's achievement and also strengthening their character (Haryanti: 2017).

Initiated by the school in collaboration with the parents' association, parent's classes run at least twice a year. Parents' classes are held at school or outside the school, parents can come from outside the school, the material is about parenting and according to the needs of parents.

\subsection{The Importance of Research}

Research is beneficial for the management of education, especially for partnerships of parents with schools, teachers, students and the community and the government. The results of the study will serve as a guideline in raising awareness, parental participation in children's education so that the alignment of the school's educational process with the family occurs.

Schools can implement it as a mandatory program and set out in the School Work Plan routinely. To the homeroom teacher will make it easier for them to detect assessing children's development. Students will receive more attention from parents. Parents can better understand the role in educating children.

\subsection{Research limitations}

This study recognizes limitations not only in terms of scope and focus but also in statistical tools, time frames, sampling methods, and others. The scope and time frame only focus on 4 state junior high schools in the city of Binjai. In addition, only basic statistics are used because this research is descriptive in nature. Finally, purposive sampling is used in selecting research respondents.

\subsection{Place of Research}

This research was conducted at the City of Binjai Middle School in 2017 until 2018 for one school year. Particularly in four state junior high schools namely 
SMP 5, SMP 6, SMP 9, and SMP Negeri 1. The target of the study was specifically for parents who had eighth grade students.

\section{Research Design And Methodology}

The study design is a combination of descriptive and qualitative using primary and secondary data. To find out the impact felt by parents from parents' class activities on the involvement of parents in children's education, this study uses data collection techniques through questionnaires, observations, interviews and documentation.

\subsection{Research respondents}

The respondents of this study were 87 parents who were a sample of 668 parents who had 7th grade children from 4 state junior high schools in Binjai City in 2017-2018. They were chosen using the Slovin formula as follows:

$$
\begin{aligned}
\mathrm{n}=\frac{\mathrm{N}}{1+\mathbb{N} \cdot \mathrm{e}^{2}} & \\
\mathrm{n} & =\frac{668}{1+668 \cdot 0 \cdot 10^{2}} \\
\mathrm{n} & =\frac{668}{7 \cdot 68} \\
\mathrm{n} & =86,979=87
\end{aligned}
$$

$\mathrm{N}=$ Population $\mathrm{n}=$ sample size

$\mathrm{e}=$ Marginal error $(10 \%)$ Computation

\subsection{Sampling Procedure}

The sampling procedure used in this study is purposive / selective sampling, parents are chosen based on the level of attendance in the class of parents. Furthermore, sampling from 4 schools was carried out proportional stratification to get the total number of respondents determined from two four schools, namely 5: 14 public SMP, 6 public SMP $=32$ people. Public Middle School $9=25$ people, Public Middle School $12=16$ people.

\subsection{Research Instruments}

In collecting primary data, the instruments used were questionnaires, observation guidelines, interview guidelines. The data that was extracted was the social conditions of parents, the implementation of parental support in the organization of children's education. 


\subsection{Data Collection Procedure}

First, the researcher sent a letter addressed to the Binjai City Education Office asking for recommendations from the junior high school for the reference to the application of the parent class program. then administering the pretesting questionnaire to validate the instrument. Third is the actual sampling and identification by researchers of the actual respondents.

\subsection{Statistic analysis}

The statistical tool used in this research is to use the SPSS software version 22, and then to do descriptive statistics such as percentages, frequencies, and averages, then a paired $t$ test (comparing pre-test and post-test scores) is used to determine the impact of parental classes on people's support. in child education. To complete the results of the quantitative analysis, a qualitative analysis of the data collected was done through interview guidelines and observation guidelines.

\section{Findings And Conclusions}

The findings of the study are the characteristics of parents based on: age, sex, education, and occupation. The data is shown on the table.

Table 1. Data of Respondents

\begin{tabular}{|c|l|r|}
\hline Categories & \multicolumn{1}{|c|}{ Description } & \multicolumn{1}{c|}{$\%$} \\
\hline \multirow{4}{*}{ AGE } & $26-35$ & $42.60 \%$ \\
\cline { 2 - 3 } & $36-45$ & $52.80 \%$ \\
\cline { 2 - 3 } & $46-55$ & $4.60 \%$ \\
\hline \multirow{3}{*}{ GENDER } & $\mathrm{F}$ & $77 \%$ \\
\cline { 2 - 3 } & $\mathrm{M}$ & $23 \%$ \\
\hline \multirow{3}{*}{ EDUCATION } & SARJANA & $9.20 \%$ \\
\cline { 2 - 3 } & SMA & $48 \%$ \\
\cline { 2 - 3 } & SMP & $27.60 \%$ \\
\cline { 2 - 3 } & SD & $14.90 \%$ \\
\hline OCCUPATION & Entrepreneur & $45.70 \%$ \\
\hline
\end{tabular}




\begin{tabular}{|l|l|r|}
\hline \multirow{4}{*}{ Private } & $17 \%$ \\
\cline { 2 - 3 } & Labor & $14.30 \%$ \\
\cline { 2 - 3 } & Farmer & $12 \%$ \\
\cline { 2 - 3 } & Government Employee & $7.80 \%$ \\
\cline { 2 - 3 } & House Wife & $3.20 \%$ \\
\hline
\end{tabular}

Source: Data of Research

The findings of the study are that the characteristics of parents based on age according to the age of most of the study respondents were mothers aged 36-45 years as many as 46 people (52.8\%), aged 26-35 years as many as 37 people (42.6\%) and ages 46-55 years $(4.6 \%)$. Age is one of the factors that can determine a person's maturity both in thinking, acting, and learning (Hurluck: 2011)

Based on the sex of the majority of respondents were 67 mothers (77\%), 20 people (23\%) were fathers. This is not surprising because generally women are always ready to accompany children. Gender is one of the factors that affects the mother usually is more caring nature while ordinary fathers lead. Fathers usually teach safety to children and courage in starting something new. While mothers tend to look after and keep their little ones in good condition (Hurluck: 2011)

Based on the level of education, the majority of educated high school 42 people (48.3\%), junior high, 24 people (27.6\%), elementary 13 people (14.9\%) and 8 people bachelor $(9.2 \%)$. Education is very important in influencing one's mind. Parents who have a lot of information about parenting through books, seminars, etc. will be more open to trying new parenting outside their parents' training. (Hurlock: 2011)

Based on the type of work, generally parents work as entrepreneurs 40 people (45.7\%), 15 people (17\%) as private employees, 12 people as laborers (14.3\%). 10 people (12\%) as farmers, 7 people $(7.8 \%)$ as civil servants and 3 people are housewives. Parents who are respondents are parents who are always present in the parent class. The parent class in this study had been held 4 times. The steps for implementing the parent class are: a planning stage (The school provides socialization to parents, the formation of parents 'groups, election of administrators, preparation of parents' class designs includes schedules, materials, places, resource persons, and supporting materials. B. Implementation (the class of parents is carried out according to the plan facilitated by the school and assisted by the management of the association) c. The result is an increase in parental understanding which has a 
positive impact on children's attention.

The association of people coordinates the activities guided by the homeroom teacher. The class community as a group of parents from the same class coordinates with each other, working together to support the program of parent involvement in children's education. Parents' class activities are carried out in the children's study room/and in the school hall. The material discussed is positive parenting, educating children in the digital age, early psychological support to children, early detection of drug abuse, habituation of good practice of worship at home, habituation of child learning assistance and other materials according to parents' needs.

Participation of participants in program activities is good, the level of parental attendance is $78 \%$, however there are still some parents who have not maximally participated in the activity. The method used in this activity is lecture, discussion and question and answer. In the classroom, more parents discuss their problems with children in the home care process. Evaluation of increasing parental understanding is done during the parent's class process and after parents apply it at home (parents are given a control card to familiarize good practices at home from getting up early to going to bed every night

Table 2. Result of Model Effectiveness Test (Test $t$ Statistics)

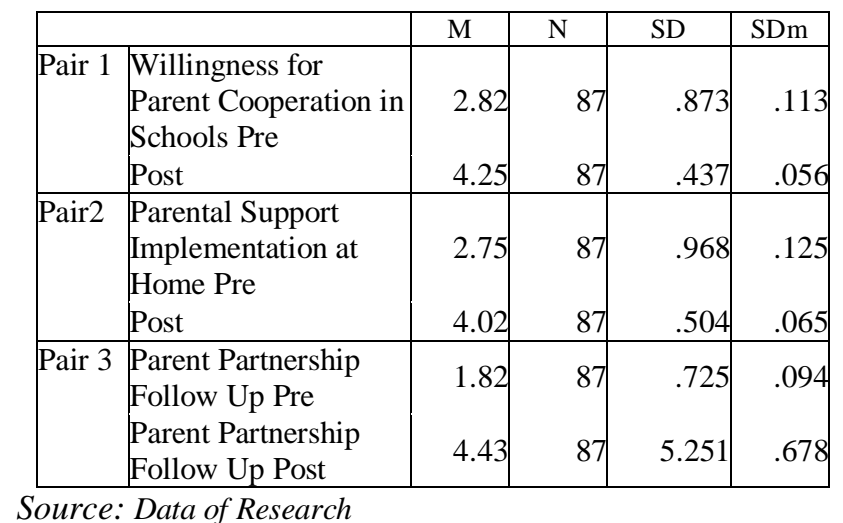

From the results of the analysis of the effectiveness of parental classes using paired sample $\mathrm{t}$ test information obtained that all parental support variables have a significant value of change ( 2 tailed) that is 0,001 (below 0.05) which means that all variables experienced significant changes after the parent class. The effectiveness of the parent class is analyzed by comparing support before the parent class program is 
conducted (pre test) with after taking the parent class 4 times (post test)

Parental support in the family is manifested in the seriousness with the family to accustom children to worship according to their religion, provide breakfast / meal before going to school, habituate children to say goodbye when going to school, welcome children when they come home from school, be a good listener for children, agree on family rules ( hours of study, hours of sleep,), support children to learn, create a safe and comfortable atmosphere at home, contact the homeroom teacher when the child is not going to school (via telephone / SMS or other means), familiarize clean and healthy life, conduct activities with children ( worship, sports, recreation), supporting the interests and potential of children, in educating children not to use violence, seeing, hearing and providing support when children experience personal problems;

These results support research conducted by Setijaningsih and Martiningsih (2014) that parenting classes have a positive effect on Parental Knowledge and attitudes in Early Childhood Basic Fulfillment, Parenting Program Implementation has a positive impact in Fostering Positive Parenting Parenting Behavior. Furthermore parent class is a means to strengthen the relationship between parents and other parents, parents and teachers, parents and resource persons.

After participating in the parent's class program activities, parents' knowledge and understanding of educating and caring for children in the family increases, changes in parental behavior and attitudes are better and more appropriate, giving them information related to assisting children in the digital age, helping them motivate children's learning, become wiser in assisting children using the internet, giving them good opportunities for effective forums in class discussions, helping them increase their participation in school.

The results of this study support the research conducted by Mulyono and Akhyadi (2018) that motivation to learn and the process of socialization of children is much developed after the parenting approach is improved in accordance with the parenting program pattern given at the time the service program is performed. This learning motivation is indicated by the increasingly intensive presence of children in learning at school, enthusiasm in learning, activities in the community and family environment that is getting better, the ability to ask questions that are also getting better and mastery of language to criticize the condition of the environment.

In addition, the parent class program also has an impact on the ability of parents to communicate. When parents tell each other about their parents about experiences in 
parenting. The more frequent communication occurs, the more courageous and skilled parents motivate each other. The program has succeeded in increasing collaboration between parents through parent class activities that are sometimes carried out in each other's homes.

Parent classes also enhance good synergy between schools and parents in the implementation of parent classes from planning to implementation. Parents and the school, especially the homeroom teacher, are increasingly open to discussing child development because the homeroom teacher always provides support, guidance on parents' class activities.

\section{Recommendation}

First, all state junior high schools and all grade levels must apply the parent class as a means of increasing parental understanding and knowledge about child care and assistance. Second, schools should arrange parent classes as a form of parent involvement in the school and include them in the RKT. Third, there must be proper and regular monitoring of parents' classes by the school so that the sustainability of the program is maintained.

\section{REFERENCES}

Azwar, (2006), Sikap Manusia, Teori dan Pengukurannya edisi ke-2 cetakan ke IV, Yogyakarta: Pustaka Belajar

Haryanti, (2017), Dwi,M.PdI, Keterlibatan Keluarga Sebagai Mi tra dalam Pendidikan Anak, Jurnal Noura, Vol. 1 No. 1,

Hurlock, Elizabeth B. (2011). Psikologi Perkembangan : Suatu Pendekatan Sepanjang Rentang Kehidupan. Jakarta : Erlangga

Kementerian Pendidikan dan Kebudayaan, (2017), Peraturan Menteri Pendidikan No.30 Tahun 2017 Tentang Pelibatan Keluarga pada Penyelenggaraan Pendidikan: Jakarta

Khasanah.U,(2017), Analisa Prakti Pelibatan Orang Tua dan Masyarakat dalam Kegiatan Kreatif Anak Usia Dini : Studi Kasus di TK Pertiwai Ds. Tambah Rejo, Jurnal Pendidikan Islam

Kimaro, A.R, Machumu, (2015), A Impacts of parental involvement in school activities 
on academic achievement of primary school children, International Journal of Education and Research, Vol. 3 No. 8 August 2015

Mulyono D, Akhyadi A.S, (2018), Program Parenting dalam Meningkatkan Kualitas Pendidikan Keluarga, Siliwangi: Jurnal Pengabdian Kepada Masyarakat (Abdimas) IKIP Siliwangi Volume 1 Nomor 1, Januari 2018

National Academies of Science, Engineering, and Medicine, (2016), Parenting matters: Supporting parents of children ages 0-8. Retrieved from https://www.nap. edu/catalog/21868/ parenting-matters-supporting-parents-of-childrenages-0-8

Noerani Resiani, (201)7, Implementasi Program Parenting Dalam Menumbuhkan Perilaku Pengasuhan Positif Orang Tua Di PAUD Tulip Tarogong Kaler Garut, Jurnal Pendidikan Luar Sekolah Volume 13, Nomor 2, Oktober 2017

Pramono.E.S, Persada.M.N, Murwatiningsih, 2017, Pelibatan Orang Tua pada Pendidikan Anak di SD Sains Islam Al Farabi Sumber Cirebon, Journal Education Management, Universitas Negeri Semarang

Wilder Research. (2016). The benefits of parenting education: A review of the literature for the Wilder Parent Education Center. Retrieved from https://www.wilder.org/ wilderresearch/research-library/benefits-parenting education-review-literaturewilderparent

Wilkes S, Harris.E, Rosenberg.H, Joining Forces: Families and Out of School Programs as Partners in supporting Children's Learning and Development, Harvard Family Research Project (https://www.education.ne.gov/wp-content/uploads/2017/07/ HarvardFamily.pdf diakses 10 Maret 2019)

Setijaningsih.T, Martiningsih W, 2014, Pengaruh Program Parenting Terhadap Pengetahuan dan sikap Orang Tua dalam Pemenuhan Dasar Anak Usia Dini,Jurnal Ners dan Kebidanan Vol 1 No 2, Poltekkes Malang 